\title{
Pengembangan Model Pembelajaran Discovery Learning dengan Data Sharing Technology pada Pokok Bahasan Energi
}

\author{
Utari Ayu Wardani, Ishafit \\ Program Studi Pendidikan Fisika Universitas Ahmad Dahlan \\ Jl. Dr. Soepomo, SH., Janturan, Warungboto, Umbulharjo, Yogyakarta, Indonesia \\ Surat-e: utariayuwardani@gmail.com
}

\begin{abstract}
Proses pembelajaran fisika terdiri dari dua aspek yaitu teori dan eksperimen sehingga diperlukan suatu metode yang melibatkan kedua aspek tersebut. Data Sharing bisa menjadi alternatif karena melibatkan teori dan eksperimen. Pada penelitian kali ini digunakan model pembelajaran Discovery Learning dimana model Discovery Learning pada pokok bahasan energi. Penelitian ini bertujuan untuk mengembangkan dan mengetahui kelayakan instrumen pendukung dalam model pembelajaran Discovery Learning dengan Data Sharing . Pada proses pembelajaran menggunakan apparatus eksperimen yang dilengkapi panduan. Metode pengumpulan data dalam penelitian ini adalah metode angket yang diujikan terdiri dari angket validasi ahli, angket uji pengguna, angket persepsi siswa, dan lembar pengamatan kemampuan afektif siswa. Hasil penelitian ini menunjukkan nilai kelayakan panduan sebesar $85,74 \%$ dan $87,87 \%$ termasuk dalam kategori baik. Tingkat persepsi siswa yang masih rendah adalah aspek motivasi. Hambatan yang ditemui dalam proses pembelajaran yaitu beberapa siswa masih ramai, suka berbicara sendiri dan beberapa siswa mengalami kesulitan dalam analisis data.
\end{abstract}

In the process of physics learning there are two important aspect; theory and experiment, so a method that can combine these aspects is needed. Data sharing technology can be the alternative media; through this media these aspects can be combined. Energy is the main topic in this research and thought with Discovery Learning method. This research aimed to develop and validate media which is used in this learning method; Discovery Learning with Data Sharing Technology. An experiment apparatus is used in the learning process. For data collection, survey method is applied. There are expert surveys, user surveys, student perception surveys, and student affective form control. The result for this research is about $85,74 \%$ and $87,87 \%$ which categorized in a good level.

Kata kunci: Discovery Learning, Data Sharing, energi

\section{PENDAHULUAN}

Pendidikan merupakan kegiatan mengoptimalkan perkembangan potensi, kecakapan dan karakteristik pribadi peserta didik [I]. Pendidikan dapat berlangsung secara formal maupun nonformal. Proses pendidikan dapat berlangsung di manapun seperti sekolah, keluarga maupun masyarakat. Peserta didik dapat belajar banyak hal.

Pembelajaran sering kali menekankan pada kegiatan mengingat dan memahami tanpa harus mengembangkan keterampilan berfikir. Kegiatan tersebut membuat siswa hanya menerima dan mempelajari konsep-konsep yang sudah jadi sehingga enggan untuk mencoba dan menemukan sendiri. Fakta tersebut menunjukkan bahwa pembelajaran fisika belum berorientasi pada proses saintifik.

Pendekatan saintifik dalam pembelajaran sains sangat cocok dengan teori konstruktivis sehingga pembelajaran menjadi lebih bermakna [2]. Mengajarkan IPA dengan pendekatan saintifik juga berarti melatihkan keterampilan proses sains yang memfasilitasi siswa untuk memahami sains sebagaimana sains ditemukan dan mendorong siswa untuk 
menciptakan informasi ilmiah melalui penelitian ilmiahnya. Discovery Learning merupakan model pembelajaran berbasis penemuan sehingga siswa tidak diberikan hasil final. Siswa berperan sebagai scientist untuk menemukan suatu teori.

Proses pembelajaran fisika di lingkup sekolah misalnya saat ini masih cenderung menggunakan media yang konvensional, tidak terkecuali pada saat melakukan eksperimen. Eksperimen fisika belum menggunakan software dalam pengumpulan data maupun analisisnya, serta perangkat lain seperti sensor. Logger Pro merilis fitur terbarunya yaitu Data Sharing yang memungkinkan uset menerima data secara real time dari Data Sharing Source. Dengan adanya Data Sharing, jumlah apparatus eksperimen yang digunakan cukup satu saja yang digunakan sebagai Data Sharing source.

Hukum kekekalan energi mekanik merupakan topik yang cenderung abstrak padahal sangat erat kaitannya dengan kehidupan sehari-hari. Siswa lebih banyak menghitung nilai energi mekanik dari soal-soal yang diberikan tanpa memahami lebih jauh tentang penerapannya dalam kehidupan sehari-hari.

\section{KAJIAN PUSTAKA}

Penelitian dengan judul "Penerapan Pembelajaran Penemuan (Discovery Learning) untuk Meningkatkan Pemahaman Konsep Fisika Siswa SMP” dapat disimpulkan bahwa terdapat peningkatan pemahaman konsep siswa setelah diterapkan model pembelajaran penemuan (Discovery Learning). Peningkatan pemahaman konsepnya berada pada kategori sedang dengan rata-rata gain yang dinormalisasi sebesar 0,608 [3].

Metode Discovery Learning adalah teori belajar yang didefinisikan sebagai proses pembelajaran yang terjadi bila pelajar tidak disajikan dengan pelajaran dalam bentuk finalnya, tetapi diharapkan mengorganisasi sendiri [4]. Metode Discovery Learning adalah memahami konsep, arti, dan hubungan, melalui proses intuitif untuk akhirnya sampai pada kesimpulan.

Data Sharing Technology merupakan suatu metode dalam pengumpulan data eksperimen yang memungkinkan guru dan siswa untuk mengumpulkan, menganalisis dan berbagi data secara nirkabel dari Data Sharing Source untuk perangkat yang terintegrasi dengan aplikasi pendukung Data Sharing Technology. Dengan adanya Data Sharing, setiap individu di kelas bisa menerima salinan data secara nirkabel untuk analisis. Selain itu, guru dapat berbagi data demonstrasi yang dilakukan [5].
Energi merupakan salah satu dari konsep paling penting pada sains [6]. Sebuah benda yang sedang bergerak memiliki kemampuan untuk melakukan kerja dan dengan demikian dapat dikatakan mempunyai energi. Energi gerak disebut energi kinetik, dari kata Yunani kinetikos, yang berarti "gerak". Jadi, energi kinetik adalah energi yang dimiliki suatu benda karena geraknya. Secara umum, persamaan untuk energi kinetik dapat dilihat pada persamaan (I).

$$
E_{K}=\frac{1}{2} m v^{2}
$$

Benda juga mungkin memiliki energi potensial, yang merupakan energi yang dihubungkan dengan gaya-gaya yang bergantung pada posisi atau konfigurasi benda (atau bendabenda) dan lingkungannya. Secara umum persamaan (2) dapat dilihat persamaan untuk energi potensial.

$$
E_{P}=m g y
$$

Energi mekanik didefinisikan sebagi penjumlahan antara energi potensial dan energi kinetik. Energi mekanik yang dimiliki oleh suatu benda adalah kekal. Oleh karena itu, jika tidak ada energi yang hilang maka akan selalu berlaku hukum kekekalan energi mekanik yang dapat dihitung dengan persamaan (3).

$$
\begin{aligned}
E_{M_{1}} & =E_{M_{2}} \\
E_{K_{1}}+E_{P_{1}} & =E_{K_{2}}+E_{P_{2}} \\
\frac{1}{2} m v_{1}^{2}+m g h_{1} & =\frac{1}{2} m v_{2}^{2}+m g h_{2}
\end{aligned}
$$

\section{METODE PENELITIAN/EKSPERIMEN}

Penelitin ini termasuk penelitian dan pengembangan atau Research and Development. Metode penelitian yang digunakan adalah metode ADDIE yang terdiri dari tahap Analysis (Analisis), Design (Desain), Development (Pengembangan), Implementation (Implementasi), dan Evaluation (Evaluasi). Instrumen penelitian ini menggunakan angket yang terdiri dari angket persepsi siswa dan angket uji kelayakan panduan.

\section{HASIL PENELITIAN DAN PEMBAHASAN}

Instrumen pendukung dalam model pembelajaran Discovery Learning berupa apparatus eksperimen yang dilengkapi panduan. Panduan terdiri dari dua jenis yaitu panduan untuk guru dan siswa. Panduan untuk guru berisi materi pembelajaran, langkah pembelajaran dan analisis data, sedangkan panduan untuk siswa berisi materi dan langkah pembelajaran saja. Susunan apparatus, tampilan 
sampul panduan dan proses kegiatan berturut-turut dapat ditampilkan seperti pada gambar I, 2 dan 3.

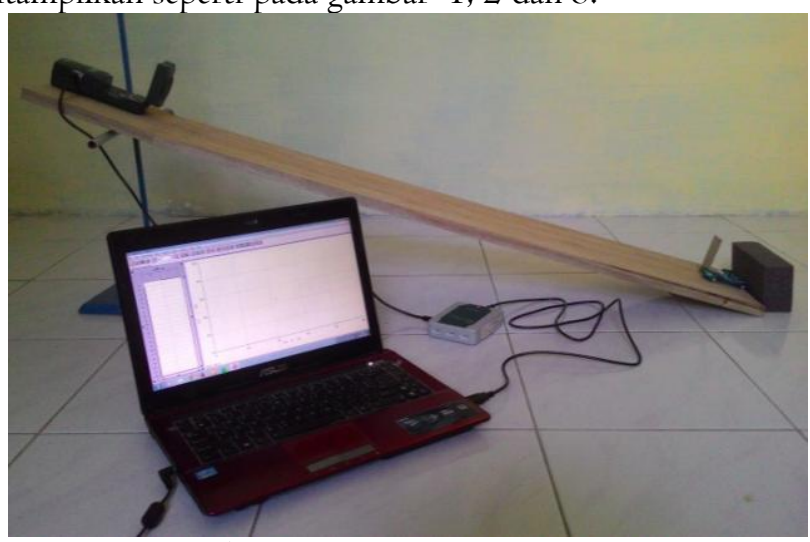

Gambar I. Susunan apparatus eksperimen

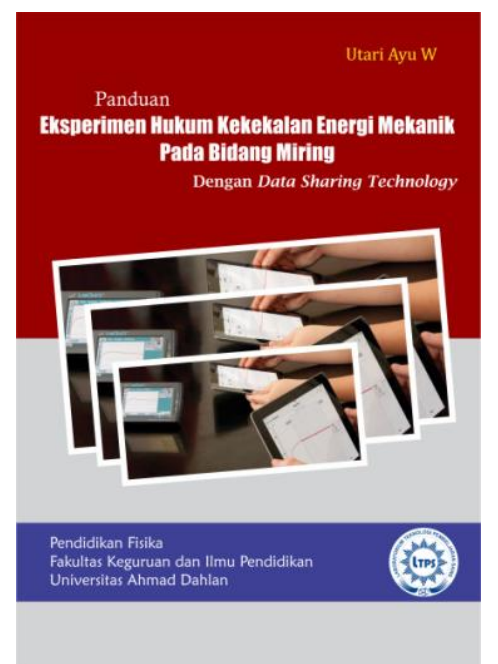

Gambar 2. Tampilan sampul panduan eksperimen hukum kekekalan energi pada bidang miring

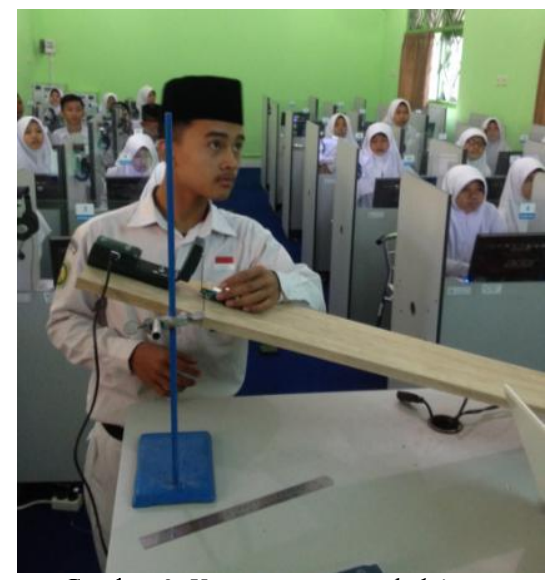

Gambar 3. Kegiatan saat pembelajaran
Proses pembelajaran meliputi eksperimen sederhana yang dilakukan guru dan dibantu siswa. Angket proses pembelajaran diberikan pada siswa sebelum proses pembelajaran berlangsung. Secara keseluruhan proses pembelajaran berjalan baik dan kondusif meskipun masih dipenuhi beberapa hambatan yang ditemukan. Dalam uji coba ini menggunakan angket yang terdiri dari dua jenis yaitu angket validasi panduan dan angket proses pembelajaran menggunakan model Discovery Learning.

Angket diujikan kepada ahli sebanyak lima orang dan pengguna sebanyak 25 orang dengan persentase berturutturut dengan rata-rata $87,87 \%$ dan $85,74 \%$. Dari angket persepsi siswa, pembelajaran Discovery Learning dengan Data Sharing masih rendah untuk aspek motivasi.

\section{KESIMPULAN}

Kesimpulan yang dapat diambil dalam penelitian pengembangan ini adalah:

I. Telah dikembangkan model pembelajaran Discovery Learning dengan Data Sharing Technology pada pokok bahasan energi.

2. Model pembelajaran Discovery Learning dengan Data Sharing Technology pada pokok bahasan energi telah diimplementasikan dengan persentase persepsi siwa terrendah pada aspek motivasi dan persentase panduan eksperimen sebesar $87,87 \%$ untuk uji ahli dan $85,74 \%$ untuk uji pengguna.

\section{Kepustakaan}

[I] Sukmadinata, P. D. (2013). Metode Penelitian Pendidikan. Bandung: Remaja Rosdakarya.

[2] Wakhidah, N. (2015, Januari 5). Pembelajaran Sains dengan Pendekatan Saintifik dan Literasi Sains. Dipetik April 24, 20I5, dari http://www.ispi.or.id/

[3] Ibrahim, M. (2013). Penerapan Pembelajaran Penemuan (Discovery Learning) untuk Meningkatkan Pemahaman Konsep Fisika Siswa SMP. Skripsi. Bandung: Universitas Pendidikan Indonesia.

[4] Kementrian Pendidikan dan Kebudayaan. (2013). Model Pembelajaran Penemuan (Discovery Learning). Dipetik April I0, 2015, dari http://docs.google.com/document

[5] Vernier. (2013). Vernier Data Share. Dipetik April I3, 2015, dari http://vernier.com/products/software/data-share/

[6] Giancoli, D. C. (200I). FISIKA (5th edition ed.). Jakarta: Erlangga. 